\title{
PENGARUH BIAYA SUMBER DAYA MANUSIA DAN PENGUKURAN NILAI SUMBER DAYA MANUSIA TERHADAP PELAPORAN AKUNTANSI SUMBER DAYA MANUSIA PADA PT BANK ACEH SYARIAH KANTOR PUSAT
}

\author{
Sri Mulyati ${ }^{1}$ Hayatun Nafiza $^{2}$ \\ 1,2Program Studi Akuntansi FEB Universitas Malikussaleh \\ ${ }^{1}$ srimulyati@unimal.ac.id, ${ }^{2}$ hayatunnafiza488@gmail.com
}

\begin{abstract}
This study aims to determine and analyze the effect of human resource costs and measurement of the value of human resources on the reporting of human resource accounting at PT Bank Aceh Syariah Head Office. This study uses primary data obtained by distributing questionnaires to all respondents. The samples in this study are selected using Purposive sampling. The sample in this study is 60 permanent employees at PT Bank Aceh Syariah. The data analysis method used is multiple linear regression with the help of SPSS 16.0. The results show that the cost of human resources affects the reporting of human resource accounting at PT Bank Aceh Syariah Head Office, and the measurement of the value of human resources affects the reporting of human resource accounting at PT Bank Aceh Syariah. Simultaneously, the cost of human resources and the measurement of the value of human resources affect the reporting of human resource accounting at PT Bank Aceh Syariah Head Office.
\end{abstract}

Keywords: Human Resource Costs, Measurement of Human Resource Value, Reporting of Human Resource Accounting

\section{PENDAHULUAN}

Akuntansi merupakan Akuntansi merupakan suatu sistem untuk menghasilkan informasi keuangan yang digunakan oleh para pemakainya dalam proses pengambilan keputusan bisnisnya. Tujuan informasi tersebut adalah memberikan petunjuk dalam memilih tindakan yang paling baik dalam mengalokasikan sumber daya yang langka pada aktivitas bisnis dan ekonomi. Namun, pemilihan dan penetapan suatu keputusan bisnis perlu ada sumber daya manusia yang memadai dari pihak-pihak pengambil keputusan. Sumber daya manusia (Human Resource) merupakan aset penting yang harus dimiliki dan diperhatikan oleh manajemen.

Sumber daya manusia menurut Wirawan (2015:2), adalah orang yang disebut manajer, pegawai, karyawan, buruh atau tenaga kerja yang bekerja untuk organisasi. Pada perusahaan jasa dan industri yang berskala besar, sumber daya manusia merupakan salah satu faktor penting dalam proses pencapaian tujuan perusahaan yaitu menghasilkan laba maksimum untuk jangka panjang. Untuk mendapatkan sumber daya manusia yang berkualitas, perusahaan perlu mengeluarkan biayabiaya yang menunjang kelangsungan hidup perusahaan di masa yang akan datang. Menurut Mulyadi (2015:8), biaya adalah pengorbanan sumber ekonomis yang diukur dalam satuan uang yang telah terjadi, sedang terjadi atau yang kemungkinan akan terjadi untuk tujuan tertentu. Biaya-biaya yang dikeluarkan oleh perusahaan tersebut yaitu biaya untuk mendapatkan atau mengganti karyawan, seperti biaya pengrekrutan, pelatihan-pelatihan, tunjangan-tunjangan tunjangan, biaya pengganti karyawan dan segala biaya-biaya yang berhubungan dengan sumber daya manusia.

Sumber daya manusia memiliki sifat yang tidak dapat diukur dengan satuan moneter, saat ini informasi akuntansi belum mengungkapkan sumber daya manusia. Adapun tujuan pengungkapan sumber daya manusia adalah untuk mengidentifikasi perubahan nilai sumber daya manusia, dengan demikian dapat diketahui sumber daya manusia mengalami peningkatan atau penurunan pada periode tertentu. Namun pengungkapan nilai sumber daya manusia belum bisa dilaporkan dalam neraca, karena sumber daya manusia belum bisa dikatakan sebagai suatu aset. Menurut Tunggal (2009), sesuatu yang dapat dikatakan sebagai aset apabila telah memiliki sifat measurement (dapat diukur), relevance dan reliability.

Salah satu Badan Usaha Milik Daerah Aceh yang bergerak di sektor jasa perbankan adalah PT Bank Aceh Syariah. Perusahaan tersebut merupakan jasa perbankan berskala besar dan juga merupakan jasa perbankan yang memiliki jumlah sumber daya paling banyak di Aceh. PT Bank Aceh Syariah juga memiliki sumber pendanaan dari dua sumber yaitu dari APBA dan pembiayaan PT Bank Aceh itu sendiri. Dalam rangka pengembangan Sumber Daya Insani, PT Bank Aceh Syariah berencana melaksanakan pendidikan dan pelatihan internal maupun eksternal. Selain itu, dalam rangka memenuhi kebutuhan karyawan SDI, PT Bank Aceh Syariah berencana melakukan rekrutmen 
karyawan sebagai tenaga kerja baru untuk menggantikan karyawan yang akan menjalani masa pensiun, mengantisipasi kekurangan karyawan dan untuk memenuhi kebutuhan SDI.

Adapun data pengeluaran biaya yang dikeluarkan PT Bank Aceh Syariah untuk sumber daya manusia dan feed back yang didapatkan dari pengeluaran tersebut selama 3 (tiga) tahun terakhir, dapat dilihat pada tabel 1.1 berikut:

Tabel 1

Jumlah Gaji Pokok dan Tunjangan Lainnya Karyawan PT Bank Aceh Syariah Tahun 20152017.

\begin{tabular}{|l|c|c|}
\hline Thn & $\begin{array}{c}\text { Biaya Sumber } \\
\text { Daya Manusia }\end{array}$ & $\begin{array}{c}\text { Kontribusi } \\
\text { Sumber Daya } \\
\text { Manusia }\end{array}$ \\
\hline 2015 & 314.241 .732 .101 & 386.859 .276 .803 \\
\hline 2016 & 334.956 .577 .182 & 391.551 .390 .852 \\
\hline 2017 & 364.876 .000 .000 & 98.730 .076 .513 \\
\hline
\end{tabular}

Sumber: Laporan Sumber Daya Insani PT Bank Aceh Syariah 2015-2017

Data diatas menunjukkan bahwa biaya yang dikeluarkan PT Bank Aceh Syariah setiap tahunnya bertambah, namun feed back yang didapatkan mengalami penurunan pada tahun 2017. Pada tahun 2015 dan 2016 terlihat kontribusi sumber daya manusia lebih besar dari pada biaya yang dikeluarkan untuk sumber daya manusia, artinya PT Bank Aceh Syariah mendapatkan feed back yang baik dari sumber daya manusia atau karyawan perusahaan. Dari ke tiga tahun tersebut terlihat bahwa pada tahun 2017 biaya yang dikeluarkan lebih besar dari pada tahun 2015 dan 2016, Namun kontribusi yang diberikan sumber daya manusia pada tahun 2017 mengalami penurunan yang signifikan.

Menurut pejabat kantor PT Bank Aceh Syariah, hal tersebut terjadi dikarenakan pengalokasian anggaran biaya pada tahun 2017 tidak seimbang atara biaya pengrekrutan dengan biaya pelatihan, dimana $30 \%$ dianggarkan untuk pelatihan dan $70 \%$ untuk biaya pengrekrutan. Oleh karena itu, pada tahun 2018 PT Bank Aceh Syariah telah memiliki rencana pendidikan dan pelatihan SDI untuk dengan anggaran sebesar Rp22.525.000.000,- dengan rasio jumlah pegawai yang mengikuti pelatihan sebesar $30 \%$. Selain itu, PT Bank Aceh Syariah juga akan melakukan Rencana Pemenuhan Uji Kompetensi Sertifikasi Profesi Perbankan dengan anggaran sebesar Rp500.000.000,- dengan rasio peserta yang wajib lulus $75 \%$. Kemudian dalam rangka meningkatkan motivasi kerja, loyalitas karyawan, dan untuk meghindari hal yang sama pada tahun 2018, PT Bank Aceh Syariah juga berkomitmen dalam meningkatkan kesejahteraan karyawan dengan mengeluarkan biaya sebagai gaji pokok dan program kesejahteraan lainnya.

Dalam hal pengukuran nilai sumber daya manusia, PT Bank Aceh Syariah melakukan uji kelulusan karyawan sesuai dengan prosedur yang telah ditetapkan oleh PT Bank Aceh Syariah dan dengan hal tersebut karyawan berhak mendapatkan nilai lebih atas prestasi dan loyalitas yang telah diberikan untuk perusahaan. Pengukuran berdasarkan kemampuan masih menjadi pro dan kontra jika dinilai dengan satuan moneter dikarenakan sumber daya manusia merupakan subjek yang sangat susah apabila diukur dengan uang, namun PT Bank Aceh Syariah melakukan pengukuran dengan melihat prestasi dan feedback yang diberikan kepada perusahaan. Oleh sebab itu PT Bank Aceh Syariah setiap tahunnya memberikan pelatihan dan pendidikan kepada karyawan agar memberikan nilai lebih pada setiap karyawan untuk terus mengejar prestasi dan menghasilkan kinerja yang memuaskan baik dalam perusahaan maupun diluar perusahaan.

Berdasarkan teori mengenai akuntansi sumber daya manusia menunjukkan bahwa terdapat hubungan yang bermakna antara biaya sumber daya manusia dan pengukuran nilai sumber daya manusia berguna untuk membantu manajerial dalam mengambil keputusan serta menunjukkan investasi perusahaan terhadap sumber daya manusia yang bersifat jangka panjang. Konsep akuntansi sumber daya manusia dapat memberikan informasi secara kuantitatif dan kualitatif tentang sumber daya manusia perusahaan, dapat membantu manajemen untuk mengelola sumber daya manusianya serta mengambil keputusan yang tepat.

\section{Rumusan Masalah}

Adapun rumusan masalah yang diangkat peneliti dalam penelitian ini yaitu:

1. Apakah biaya sumber daya manusia berpengaruh terhadap pelaporan akuntansi sumber daya manusia pada PT Bank Aceh Syariah?

2. Apakah pengukuran nilai sumber daya manusia berpengaruh terhadap pelaporan akuntansi sumber daya manusia pada PT Bank Aceh Syariah?

3. Apakah biaya sumber daya manusia dan pengukuran nilai sumber daya manusia berpengaruh terhadap pelaporan akuntansi sumber daya manusia pada PT Bank Aceh Syariah?

\section{Tujuan Penelitian}

Sesuai dengan permasalahan yang telah di rumuskan, maka tujuan yang ingin dicapai dalam penelitian ini adalah :

1. Untuk mengetahui pengaruh biaya sumber daya manusia terhadap pelaporan akuntansi 
Volume 8, Nomor 2, Agustus 2020

sumber daya manusia pada PT Bank Aceh Syariah.

2. Untuk mengetahui pengaruh pengukuran nilai sumber daya manusia terhadap pelaporan akuntansi sumber daya manusia pada PT Bank Aceh Syariah.

3. Untuk mengetahui pengaruh biaya sumber daya manusia dan pengukuran nilai sumber daya manusia terhadap pelaporan akuntansi sumber daya manusia pada PT Bank Aceh Syariah.

\section{TINJAUAN PUSTAKA \\ Landasan Teori \\ Teori Flamholzt}

Teori ini menyebutkan bahwa untuk menilai sumber daya manusia dapat dilihat dari interaksi dua variabel yaitu the individual's conditional value dan probabilitas dimana karyawan akan ditempatkan dalam perusahaan. Conditional value adalah yaitu jumlah yang secara potensional dapat direalisasikan dari jasa seorang yang diukur productivity, transferbility, promotability. Productivity adalah prestasi dari kinerja karyawan yang diharapakan sewaktu dia menjabat posisinya sekarang. Transferbility adalah jasa karyawan yang diharapkan jika dipindahkan pada posisi lain. Sedangkan promotability adalah jasa karyawan yang diharapkan jika menempati posisi yang lebih tinggi (Harahap, 2011:62).

\section{Akuntansi Sumber Daya Manusia \\ Menurut The American Assosiation} Committee in Human Resource dalam buku Tunggal (2009), Akuntansi Sumber Daya Manusia adalah proses pengidentifikasian dan pengukuran data mengenai sumber daya manusia dan mengkomunikasikan informasi ini terhadap pihakpihak yang berkepentingan. Dari definisi tersebut terkandung tiga pengertian Human Resource Accounting yaitu mengidentifikasi nilai manusia, mengukur cost dan value sumber daya manusia dan penyelidikan mengenai dampak kognitif dalam perilaku sebagai akibat dari informasi itu.

Perkembangan akuntansi sumber daya manusia tidak lepas dari dukungan para ilmuan yang mengkapitalisakan investasi sumber daya manusia dan mengelompokkan pada pos aktiva. Tetapi sementara itu, banyak pihak yang masih meragukan konsep akuntansi sumber daya manusia dan bahkan menentang dikelompokkannya akuntansi sumber daya manusia sebagai aktiva. Hal ini terlihat dari praktek pelaporan keuangan selama ini yang mengabaikan informasi yang sangat penting yaitu informasi tentang aktiva manusia (human assets). Perlakuan akuntansi konvensial terhadap pengeluaran-pengeluaran untuk sumber daya manusia selalu dianggap beban.

Tujuan akuntansi sumber daya manusia ini adalah memberikan informasi tentang sumber daya manusia dala suatu perusahaan yang berguna bagi pengambilan keputusan. secara umum fungsi akuntansi sumber daya manusia adalah untuk melengkapi informasi tentang nilai sumber daya manusia untuk digunakan dalam proses pengambilan keputusan tentan perolehan alokasi, pengembangan, pemeliharaan sumber daya manusia agar tercapai efektivitas tujuan organisasi, kemudian untuk memberikan informasi kepada manajer personalia agar dapat secara efektif memonitor dan menggunakan sumber daya manusia, dan membantu pengembangan prinsip manajemen dengan menjelaskan akibat keuangan dari berbagai praktik akuntansi sumber daya manusia.

Dari beberapa pernyataan di atas, dapat disimpulkan bahwa akuntansi sumber daya manusia adalah proses pengidentifikasian, pengukuran, penafsiran, pencatatan, dan pelaporan data tentang sumber daya manusia yang ada dalam perusahaan untuk kemudian diinformasikan kepada pihakpihak yang berkepentingan. Data yang diukur, dicatat, dan dilaporkan itu adalah data mengenai pengeluaran untuk sumber daya manusia yang ada dalam suatu organisasi.

Keberadaan akuntansi sumber daya manusia sangat diperlukan bagi pengambil keputusan terutama keputusan tentang sumber daya manusia itu sendiri. Dengan akuntansi sumber daya manusia, keberadaan manusia di dalam suatu perusahaan merupakan human assets, bukan hanya sebagai salah satu faktor produksi saja, tetapi juga sebagai modal dasar yang sangat penting bagi kelangsungan hidup perusahaan. Secara singkat, akuntansi sumber daya manusia mencakup akuntansi untuk manusia sebagai sumber daya organisasi untuk tujuan akuntansi manajerial dan keuangan.

\section{Pengakuan Sumber Daya Manusia Sebagai Suatu Aktiva}

Salah satu masalah pokok dalam akuntansi sumber daya manusia adalah masalah pengakuan sumber daya manusia. Sejak awal mula dilontarkannya gagasan akuntansi sumber daya manusia, sejak itu pula perdebatan tentang akuntansi sumber daya manusia tidak pernah selesai. Topik perdebatan terutama menyangkut masalah apakah sumber daya manusia dicatat sebagai aktiva ataukah sebagai beban periodik. Praktek akuntansi konvensional memperlakukan investasi dalam sumber daya manusia langsung diakui sebagai beban periode terjadinya pengeluaran-pengeluaran itu. Para pendukung akuntansi sumber daya manusia menganggap investasi sumber daya manusia mempunyai dua komponen yaitu komponen beban dan komponen investasi yang harus dikapitalisasi. Anggapan ini didasarkan pada pandangan mereka bahwa investasi sumber daya manusia mempunyai 
manfaat tidak hanya pada periode terjadinya pengeluaran saja, tetapi juga untuk masa yang akan datang.

Menurut Pernyataan Standar Akuntansi Keuangan (PSAK) hal 13 menyatakan bahwa aktiva adalah sumber daya yang dikuasai oleh perusahaan sebagai aktiva dari peristiwa masa lalu dan dari mana manfaat ekonomi di masa depan diharapkan akan diperoleh perusahaan. Ada beberapa kriteria yang harus diperhatikan apabila suatu objek dapat disebut sebagai aktiva yaitu: (a) memberi manfaat atau jasa ekonomis pada masa yang akan datang, (b) hak menguasai manfaat ekonomi tersebut ada pada perusahaan, (c) berasal dari transaksi atau peristiwa masa lalu, (d) dinyatakan dalam satuan moneter.

Agar investasi sumber daya manusia dapat dikelompokkan sebagai aktiva maka keempat kriteria di atas harus dapat diterapkan pada sumber daya manusia. Untuk kriteria yang pertama tidak menjadi masalah. Pengeluaran-pengeluaran untuk sumber daya manusia yaitu pengeluaran untuk perolehan dan pengembangan sumber daya manusia mempunyai manfaat tidak hanya dalam periode terjadinya pengeluaran saja, tetapi juga memberikan manfaat untuk beberapa periode. Demikian juga kriteria ketiga dan keempat, pengeluaran- pengeluaran untuk sumber daya manusia tersebut memang telah terjadi dalam periode yang lalu dan dinyatakan dalam satuan uang/moneter.

Dalam hal ini, yang menjadi masalah adalah kriteria kedua. Ada anggapan bahwa sumber daya manusia tidak termasuk sebagai aktiva karena manusia tidak dimiliki oleh perusahaan. Anggapan tersebut tidak benar. Maksud dari kata "dimiliki" pada kriteria kedua yaitu bahwa secara hukum sumber daya manusia memang tidak dapat dimiliki oleh perusahaan, tetapi perusahaan mempunyai hak untuk memperoleh kerja sama dari kemampuan sumber daya manusia itu untuk memberikan jasa dalam proses kegiatan produksi sesuai dengan biaya yang telah dikorbankan untuk sumber daya manusia itu pada masa yang lalu atau lebih merupakan hak operasional yang dimiliki oleh perusahaan untuk memperoleh keuntungan dan manfaat dari sumber daya manusia. Secara hukum, perusahaan tidak dapat memiliki aktiva tersebut karena sumber daya manusia dapat melakukan pemutusan hubungan kerja dengan perusahaan di tempat ia bekerja, dengan syarat tidak melanggar perjanjian kontrak kerja yang telah ditetapkan oleh perusahaan. Pemilikan sumber daya manusia secara ekonomis dapat dilihat pada perekonomian modern seperti sekarang ini yaitu sering dilakukannya jual beli antar perusahaan.

\section{Tujuan Penerapan Akuntansi Sumber Daya} Manusia

Menurut Thomas (1974) dalam Tunggal (2009) tujuan akuntansi sumber daya manusia adalah sebagai berikut:

a. Tujuan Kuantitatif

Mampu meningkatkan manfaat laporan keuangan karena memberikan informasi kuantitatif atas sumber daya manusia bagi pemakainya yang bervariasi misalnya manajemen dan investor dalam pengambilan keputusan.

b. Metode Penilaian

Metode penilaian memiliki tujuan untuk memberikan metode penilaian terhadap utilisasi sumber daya manusia.

c. Teori dan Model

Untuk memberikan suatu teori dari variabel-variabel yang relevan untuk menjelaskan nilai manusia terhadap organisasi formal, untuk mengidentifikasi variabel-variabel yang relevan, dan untuk mengembangkan model yang ideal untuk pengelolaan sumber daya manusia.

Menurut Flamholtz (1985) dalam Tunggal (2009) tujuan penerapan akuntansi sumber daya manusia adalah:

1. Menyediakan informasi yang dibutuhkan manajer dalam menggunakan human resource secara efektif dan efisien

2. Menyediakan informasi yang dibutuhkan manajemen dalam memperoleh, menempatkan, melatih, mengembangkan, mengkonversi, mengevaluasi, menilai, dan menghargai human resource.

3. Menyediakan alat pengukuran cost dan value dari manusia bagi organisasi untuk digunakan dalam pengambilan keputusan.

4. Memotivasi manajer untuk mempertimbangkan akibat pengambilan keputusan usaha atas human resource.

Dari beberapa pendapat di atas, dapat disimpulkan bahwa tujuan akuntansi sumber daya manusia ini adalah memberikan informasi tentang sumber daya manusia dalam suatu perusahaan yang berguna dalam pengambilan keputusan. Tujuan utama dari akuntansi sumber daya manusia adalah untuk membantu manajer perusahaan dalam mengukur efektivitas dan efisiensi sumber daya manusia. Hal ini semakin penting terutama dalam bisnis yang semakin kompetitif sehingga diperlukan management strategy yang tepat dalam mengelola sumber daya manusia ini. Akuntansi sumber daya manusia merupakan suatu pengakuan yang tegas atas dasar pemikiran manusia yang merupakan sumber daya organisasi yang sangat berharga dan merupakan bagian integral dari perpaduan sumber daya. 


\section{Konsep-Konsep Biaya Sumber Daya Manusia}

Biaya sumber daya manusia adalah biaya-biaya yang terjadi untuk mendapatkan atau mengganti karyawan. Biaya-biaya ini terbagi atas biaya orisinil dari sumber daya manusia dan biaya pengganti dari sumber daya manusia.

\section{Biaya Original dari Sumber Daya Manusia}

Biaya original dari sumber daya manusia merupakan pengorbanan yang terjadi untuk memperoleh dan mengembangkan manusia yang terdiri dari:

1. Biaya akuisisi

Biaya akuisisi adalah biaya yang harus terjadi untuk mendapatkan seorang karyawan yang tujuannya untuk mengisi suatu jabatan atau posisi tertentu. Biaya akuisisi terdiri dari biaya pencarian, biaya seleksi, biaya penerimaan dan penempatan, serta promotion or hiring from within firm (biaya untuk memindahkan tenaga kerja dari suatu tingkatan ke tingkatan yang lain dalam struktur organisasi baik secara vertikal maupun horizontal).

2. Biaya belajar

Biaya belajar merupakan pengorbanan yang harus terjadi untuk melatih seseorang dan membawa orang tersebut ke tingkat performa dan produktivitas yang secara normal diharapkan dari seorang individual dalam suatu posisi tertentu. Biaya belajar terdiri dari pelatihan formal dan biaya orientasi, biaya pelatihan di tempat kerja, trainer's time cost, dan kehilangan produktivitas selama pelatihan.

\section{Biaya Pengganti dari Sumber Daya Manusia}

Biaya ini merupakan biaya yang dikeluarkan oleh perusahaan untuk menggantikan sumber daya manusia yang sekarang sedang dipekerjakan. Biaya ni mempunyai suatu pengertian yang ganda yaitu:

1. Biaya pengganti posisional

Biaya ini merupakan biaya untuk menggantikan sekumpulan jasa yang dipegang oleh seorang pemegang jabatan dalam suatu posisi khusus.

2. Biaya pengganti pribadi

Biaya ini merupakan pengorbanan yang seharusnya terjadi sekarang untuk menggantikan seseorang yang pada saat ini dipekerjakan dengan suatu subsitusi yang mampu memberikan sekumpulan jasa yang sama pada semua posisi yang dijabat si pendahulu.

\section{Pengukuran Nilai Sumber Daya Manusia}

Masalah akuntansi untuk nilai sumber daya manusia berbeda secara signifikan dari masalah-masalah pengukuran biaya. Pengukuran biaya meliputi biaya dan pengakumulasiannya. Pada skala yang lebih luas, pengukuran ini merupakan proses historis. Nilai berorientasi pada masa depan bukan pada masa lalu. Dengan demikian akuntansi sumber daya manusia memerlukan ramalan dan bersifat tidak pasti. Konsep nilai manusia diturunkan dari teori umum ekonomi. Sama dengan sumber daya lainnya, manusia memiliki nilai karena mereka dapat memberikan jasa atau pelayanan dimasa depan. Dengan demikian, nilai sumber daya manusia seperti nilai sumber daya lainnya dapat didefinisikan sebagai nilai sekarang dari jasa masa depan yang diharapkan. Konsep nilai sumber daya manusia ini dapat diterapkan pada individu, kelompok dan total sistem manusia (Ikhsan, 2010:182).

Dalam mengembangkan ukuran-ukuran moneter dan non moneter dari nilai orang juga telah dikemukakan. Ukuran moneter diperlukan karena uang adalah denominator umum dari keputusan bisnis. Pada ukuran-ukuran non moneter terkadang diperlukan karena sangat bermanfaat untuk mengukur sesuatu yang tidak dapat dilakukan melalui ukuran-ukuran moneter tetapi hal tersebut penting karena ukuran-ukuran keberhasilan strategi yang diterapkan memasuki bidang-bidang lainnya.

\section{Pelaporan Akuntansi Sumber Daya Manusia}

Ada empat metode yang dapat digunakan dalam melaporkan investasi sumber daya manusia:

1. Surat untuk Direksi

Dalam surat direksi dapat dilaporkan pengeluaran-pengeluaran yang dilakukan sebagai investasi dalam sumber daya manusia selama periode berjalan. Informasi ini akan membantu investor dan analis keuangan menilai sejauh mana manajemen memberi perhatian pada pengembangan sumber daya manusia, suatu faktor kritikal dalam kemampulabaan organisasi dalam jangka panjang.

2. Laporan Aktiva Tidak Berwujud

Laporan tersebut harus menunjukkan pengeluaran yang dilakukan untuk berbagai kelompok aktiva tidak berwujud untuk periode berjalan maupun periode sebelumnya. Laporan ini dapat digunakan untuk mendeskripsikan sifat pengeluaran dan informasi lain yang relevan. Laporan ini memberikan informasi kepada investor tentang investasi dalam sumber daya manusia, tetapi meninggalkan kesulitan yang melekat di dalam masalah mengamortisasi aktiva demikian. 
Keterbatasan utama dari laporan ini adalah bahwa laporan keuangan masih terdistorsi. Neraca dapat terdistorsi karena aktiva total perusahaan (manusia, keuangan, dan fisik) kerendahan. Pengukuran pendapat terdistorsi karena semua pengeluaran untuk aktiva manusia dibiayakan dalam periode terjadi. Dengan demikian, pengukuran ROI perusahaan tetap terdistorsi.

3. Laporan Keuangan

Laporan ini mencakup kapitalisasi dan amortisasi dari investasi sumber daya manusia selama masa manfaat yang diharapkan walaupun perlakuan investasi dalam sumber daya manusia ini tidaklah umum. Namun, beberapa perusahaan telah mengikuti cara ini (seperti perusahaan penerbangan, elektronik, dan olah raga profesional di Amerika Serikat).

4. Laporan Keuangan Tambahan

Laporan yang diusulkan oleh Dr. Jaka Isgiyarta, seorang dosen Fakultas Ekonomi Universitas Diponegoro Semarang ini menyajikan informasi mengenai investasi sumber daya manusia dalam laporan keuangan tambahan. Perusahaan dapat menyusun sekumpulan laporan keuangan yang menunjukkan investasi sumber daya manusia dengan konvensi akuntansi sumber daya manusia yang diusulkan dan memasukkan laporan ini sebagai informasi tambahan dalam laporan keuangan tahunan mereka. Laporan ini akan memberikan catatan bahwa laporan keuangan tersebut sebenarnya perlu dipertimbangkan secara terpisah dari laporan keuangan konvensional.

Laporan ini bukan untuk menggantikan informasi laporan keuangan selama ini, tetapi lebih bersifat melengkapi atau menambah informasi laporan keuangan selama ini dan bersifat wajib (mandatory disclosure). Sedangkan informasi sumber daya manusia yang bersifat bukan kuantitatif-keuangan akan menjadi bagian yang tak terpisahkan dari catatan atas laporan keuangan. Laporan kuantitatif keuangan tersebut tidak mengubah komposisi informasi informasi laporan keuangan menurut Standar Akuntansi Keuangan (SAK).

Adapun item-item informasi akuntansi sumber daya manusia adalah sebagai berikut:

a. Informasi yang berkaitan dengan loyalitas dan dedikasi karyawan kepada perusahaan. Informasi ini meliputi pengeluaran-pengeluaran penghasilan kepada karyawannya, seperti gaji, tunjangan-tunjangan atau penerimaan lain.

b. Informasi yang berkaitan dengan pembelajaran berkelanjutan kepada karyawan. Informasi ini meliputi pengeluaran untuk pelatihan, studi lanjut, kursus, workshop, dan lain-lain.

\section{Kerangka Konseptual}

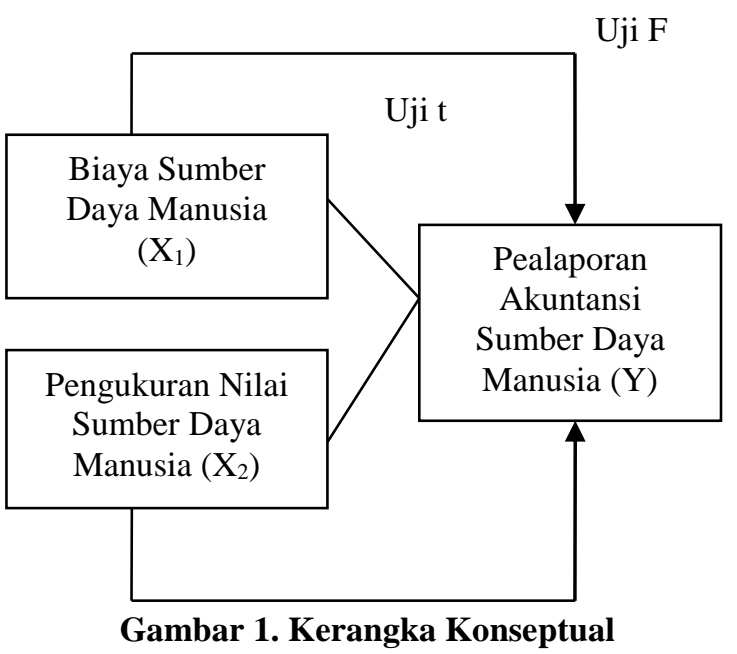

Hipotesis

Adapun hipotesis penelitian ini dapat dirumuskan sebagai berikut:

$\mathrm{H}_{1}$ : Biaya sumber daya manusia berpengaruh terhadap pelaporan akuntansi sumber daya manusia pada PT Bank Aceh Syariah.

$\mathrm{H}_{2}$ : Pengukuran nilai sumber daya manusia berpengaruh terhadap pelaporan akuntansi sumber daya manusia pada PT Bank Aceh Syariah.

$\mathrm{H}_{3}$ : Biaya sumber daya manusia dan Pengukuran nilai sumber daya manusia berpengaruh terhadap pelaporan akuntansi sumber daya manusia pada PT Bank Aceh Syariah.

\section{METODE PENELITIAN}

\section{Lokasi dan Objek Penelitian}

Lokasi penelitian merupakan tempat yang dipilih peneliti melakukan penelitian yaitu pada PT Bank Aceh Syariah Kantor Pusat yang beralamat di Jalan Mr Mohammad Hasan No. 89, Batoh, Kota Banda Aceh. Kode Pos 23245, Telepon (0651) 22996, Fax (0651) 32598.

\section{Sampel dan Populasi}

Sugiyono (2011:80), populasi adalah wilayah generalisasi yang terdiri atas objek dan subjek yang mempunyai kualitas dan karakteristik tertentu yang ditetapkan oleh peneliti untuk mempelajari. 
Populasi dalam penelitian ini adalah seluruh karyawan PT Bank Aceh Syariah sebanyak 245 orang, dan Dalam penarikan sampel peneliti menggunakan teknik purposive sampling. Purposive sampling dilakukan dengan mengambil sampel dari populasi berdasarkan pertimbangan (judgement) tertentu atau jatah (quota) tertentu (Jogiyanto, 2013). Kriteria yang digunakan dalam penelitian ini adalah sebagai berikut:

1. Seluruh karyawan PT Bank Aceh Syariah Kantor Pusat.

2. Karyawan tetap PT Bank Aceh Syariah Kantor Pusat.

3. Karyawan PT Bank Aceh Syariah Kantor Pusat yang berpendidikan terakhir Sarjana dan Pasca Sarjana.

Kriteria pengambilan sampel disajikan pada tabel 3.1 sebagai berikut:

Tabel 2

Kriteria Pengambilan Sampel

Sumber: Data diolah peneliti, 2019

Berdasarkan tabel 2 kriteria pengambilan sampel di atas, kriteria pengambilan sampel yang pertama yaitu seluruh karyawan PT. Bank Aceh Syariah Kantor Pusat dikarenakan objek penelitian peneliti berada di PT. Bank Aceh Syariah Kantor Pusat, kriteria pengambilan sampel kedua yaitu karyawan tetap PT. Bank Aceh Syariah Kantor Pusat, peneliti mengambil kriteria karyawan tetap dikarenakan pengeluaran biaya sumber daya manusia diutamakan untuk karyawan tetap, dan kriteria pengambilan sampel yang ketiga yaitu karyawan yang berpendidikan sarjana dan pasca sarjana pada PT. Bank Aceh Syariah Kantor Pusat, pengambilan kriteria tersebut dikarenakan jumlah karyawan tetap yang paling dominan adalah karyawan yang berpendidikan terakhir sarjana dan pasca sarjana.

Berdasarkan kriteria pengambilan sampel di atas, maka sampel dalam penelitian ini sebanyak 60 karyawan pada PT. Bank Aceh Syariah Kantor Pusat.

\section{Teknik Pengumpulan Data}

Teknik pengumpulan data pada penelitian ini menggunakan kuesioner yang dibagikan kepada karyawan atau staf PT Bank Aceh Syariah. Metode kuesioner merupakan teknik pengumpulan data yang dilakukan dengan cara memberi seperangkat pertanyaan atau pernyataan tertulis kepada responden untuk dijawabnya (Sugiyono, 2010:199).

\section{HASIL PENELITIAN}

Penelitian ini dilakukan pada tahun 2019, dengan jumlah sampel sebanyak 60 karyawan. Variabel Independen yang digunakan dalam penelitian ini adalah Biaya Sumber Daya Manusia dan Pengukuran Nilai Sumber Daya Manusia, variabel dependen adalah Pelaporan Akuntansi Sumber Daya Manusia. Data penyebaran kuesioner penelitian terhadap responden disajikan pada tabel berikut:

Tabel 3

Jumlah Kuesioner

\begin{tabular}{|l|c|c|}
\hline \multicolumn{1}{|c|}{ Sumber Data } & Jumlah & Persentase \\
\hline $\begin{array}{l}\text { Jumlah Kuesioner } \\
\text { yang disebar }\end{array}$ & 60 & 100 \\
\hline $\begin{array}{l}\text { Jumlah Kuesioner } \\
\text { yang kembali }\end{array}$ & 60 & 100 \\
\hline $\begin{array}{l}\text { Jumlah Kuesioner } \\
\text { yang dapat diolah }\end{array}$ & 60 & 100 \\
\hline
\end{tabular}

Sumber: Hasil Penelitian, 2019

Berdasarkan tabel 3 dapat dilihat bahwa tingkat pengembalian kuesioner sebanyak 60 kuesioner atau $100 \%$ dari jumlah kuesioner yang disebarkan.

\begin{tabular}{|c|l|c|}
\hline No & \multicolumn{1}{|c|}{ Kriteria } & Jumlah \\
\hline 1. & $\begin{array}{l}\text { Seluruh Karyawan PT Bank } \\
\text { Aceh Syariah Kantor Pusat }\end{array}$ & 245 \\
\hline 2. & $\begin{array}{l}\text { Karyawan tidak tetap PT Bank } \\
\text { Aceh Syariah Kantor Pusat }\end{array}$ & $(94)$ \\
\hline 3. & $\begin{array}{l}\text { Karyawan PT Bank Aceh } \\
\text { Syariah Kantor Pusat yang } \\
\text { berpendidikan terakhir selain } \\
\text { sarjana dan pasca sarjana }\end{array}$ & $(91)$ \\
\hline \multicolumn{2}{|c|}{ Jumlah Sampel } & $\mathbf{6 0}$ \\
\hline
\end{tabular}

Tabel 4

Karakteristik Responden

\begin{tabular}{|c|l|c|c|}
\hline No & \multicolumn{1}{|c|}{$\begin{array}{c}\text { Jenis } \\
\text { Kelamin }\end{array}$} & Frekuensi & $\begin{array}{c}\text { Persentase } \\
(\%)\end{array}$ \\
\hline 1 & Laki Laki & 40 & 66,7 \\
\hline 2 & Perempuan & 20 & 33,3 \\
\hline & Total & 60 & 100 \\
\hline
\end{tabular}

Berdasarkan tabel diatas diketahui bahwa dari 60 responden adalah terdiri 40 orang responden lakilaki atau setara dengan $66,7 \%$, dan selebihnya sebanyak 20 orang responden perempuan atau setara dengan 33,3\%. Pada penyebaran kuesioner ini yang lebih dominan untuk mengisi kuesioner adalah laki-laki dikarenakan pada PT Bank Aceh Syariah Kantor Pusat memiliki karyawan tetap yang mayoritasnya adalah berjenis kelamin lakilaki.

Tabel 5

Karakteristik Responden Berdasarkan Usia

\begin{tabular}{|c|c|c|c|}
\hline No & Usia & $\begin{array}{c}\text { Frekue } \\
\text { nsi }\end{array}$ & Persentase (\%) \\
\hline 1 & $25-40$ & 57 & 95,0 \\
\hline 2 & $>40$ & 3 & 5,0 \\
\hline
\end{tabular}




\begin{tabular}{|c|c|c|c|c|}
\hline NO & $\begin{array}{c}\text { Butir } \\
\text { Pertanyaan }\end{array}$ & $\begin{array}{c}\text { Corr } \\
\text { ected } \\
\text { Item } \\
\text { Total } \\
\text { Corr } \\
\text { elatio } \\
n\end{array}$ & rtabel & Ket \\
\hline 1 & $\begin{array}{ll}\begin{array}{ll}\text { Biaya Sumber } \\
\text { Daya Manusia } \\
\text { (X1) } \\
\text { a. } & \text { Q1X1 } \\
\text { b. } & \text { Q2X1 } \\
\text { c. } & \text { Q3X1 } \\
\text { d. } & \text { Q4X1 } \\
\text { e. } & \text { Q5X1 }\end{array}\end{array}$ & $\begin{array}{l}0,542 \\
0,683 \\
0,504 \\
0,489 \\
0,683\end{array}$ & $\begin{array}{l}0,254 \\
0,254 \\
0,254 \\
0,254 \\
0,254\end{array}$ & $\begin{array}{l}\text { Valid } \\
\text { Valid } \\
\text { Valid } \\
\text { Valid } \\
\text { Valid }\end{array}$ \\
\hline 2 & 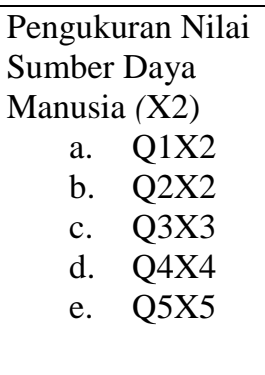 & $\begin{array}{l}0,850 \\
0,872 \\
0,839 \\
0,724 \\
0,839\end{array}$ & $\begin{array}{l}0,254 \\
0,254 \\
0,254 \\
0,254 \\
0,254\end{array}$ & $\begin{array}{l}\text { Valid } \\
\text { Valid } \\
\text { Valid } \\
\text { Valid } \\
\text { Valid }\end{array}$ \\
\hline 3. & $\begin{array}{cc}\text { Pelaporan } \\
\text { Akuntansi } \\
\text { Sumber Daya } \\
\text { Manusia (Y) } \\
\text { a. } & \text { Q1Y } \\
\text { b. } & \text { Q2Y } \\
\text { c. } & \text { Q3Y } \\
\text { d. } & \text { Q4Y } \\
\text { e. } & \text { Q5Y } \\
\text { f. } & \text { Q6Y } \\
\text { g. } & \text { Q7Y }\end{array}$ & $\begin{array}{l}0,808 \\
0,805 \\
0,642 \\
0,436 \\
0,420 \\
0,301 \\
0,363\end{array}$ & $\begin{array}{l}0,254 \\
0,254 \\
0,254 \\
0,254 \\
0,254 \\
0,254 \\
0,254\end{array}$ & $\begin{array}{l}\text { Valid } \\
\text { Valid } \\
\text { Valid } \\
\text { Valid } \\
\text { Valid } \\
\text { Valid } \\
\text { Valid }\end{array}$ \\
\hline & Total & & 100,0 & \\
\hline
\end{tabular}

Berdasarkan tabel di atas dapat diketahui bahwa dari 60 responden adalah 25 s.d 40 tahun sebanyak 57 orang responden atau setara dengan $95,0 \%$, dan usia $>40$ tahun sebanyak 3 orang responden atau setara dengan $5,0 \%$. Pada penyebaran kuesioner ini, mayoritas responden berusia 25 s.d 40 tahun, dikarenakan karyawan tetap pada PT Bank Aceh Syariah Kantor Pusat didominasi usia 25 s.d 40 tahun

Tabel 6

Karakteristik Responden Berdasarkan Pendidikan

\begin{tabular}{|c|l|c|c|}
\hline No & $\begin{array}{c}\text { Jenis } \\
\text { Kelamin }\end{array}$ & Frekuensi & $\begin{array}{c}\text { Persentase } \\
(\%)\end{array}$ \\
\hline 1 & S1 & 55 & 91,7 \\
\hline 2 & S2 & 5 & 8,3 \\
\hline & Total & 60 & 100 \\
\hline
\end{tabular}

Berdasarkan tabel di atas dapat diketahui bahwa dari 60 responden karyawan yang berpendidikan S1 sebanyak 55 orang responden atau setara dengan $91,7 \%$, dan karyawan yang berpendidikan S2 sebanyak 5 orang responden atau setara dengan $8,3 \%$. Pada penyebaran kuesioner ini, mayoritas responden adalah karyawan yang berpendidikan S1, dikarenakan karyawan tetap pada PT Bank Aceh Syariah Kantor Pusat didominasi berpendidikan terakhir S1.

Tabel 7

Karakteristik Responden Berdasarkan Status Karyawan

\begin{tabular}{|c|l|c|c|}
\hline No & \multicolumn{1}{|c|}{$\begin{array}{c}\text { Jenis } \\
\text { Kelamin }\end{array}$} & Frekuensi & $\begin{array}{c}\text { Persentase } \\
(\%)\end{array}$ \\
\hline 1 & Tetap & 60 & 100 \\
\hline 2 & Tidak teta & 0 & 0 \\
\hline & Total & 60 & 100 \\
\hline
\end{tabular}

Berdasarkan tabel di atas dapat diketahui bahwa dari 60 responden seluruhnya merupakan karyawan tetap pada PT Bank Aceh Syariah Kantor Pusat atau setara dengan $100 \%$.

Tabel 8

Hasil Uji Validitas

Berdasarkan tabel 8 di atas memperlihatkan hasil uji validitas bahwa nilai $r$ hitung setiap variabel lebih besar dibandingkan nilai $r$ tabel. Dengan demikian kuisioner yang digunakan oleh variabel dinyatakan valid untuk digunakan sebagai alat ukur variabel.

Tabel 9

Uji Reliabilitas

\begin{tabular}{|c|c|c|c|}
\hline Variabel & $\begin{array}{c}\text { Cronbach } \\
\text { Alpha }\end{array}$ & Standard & $\begin{array}{c}\text { Ketera } \\
\text { ngan }\end{array}$ \\
\hline $\begin{array}{l}\text { Biaya } \\
\text { Sumber Daya } \\
\text { Manusia } \\
\text { (X1) }\end{array}$ & 0,630 & 0,60 & Reliabel \\
\hline $\begin{array}{c}\text { Pengukuran } \\
\text { Nilai Sumber } \\
\text { Daya } \\
\text { Manusia } \\
\text { (X2) } \\
\end{array}$ & 0,876 & 0,60 & Reliabel \\
\hline $\begin{array}{c}\text { Pelaporan } \\
\text { Akuntansi } \\
\text { Sumber Daya } \\
\text { Manusia (Y) }\end{array}$ & 0,644 & 0,60 & Reliabel \\
\hline
\end{tabular}


Berdasarkan tabel 9 menunjukkan bahwa item pernyataan variabel yang diteliti adalah reliabel karena mempunyai nilai cronbach alpha> 0,60. Dengan demikian dapat dikatakan variabelnya telah handal dalam kuisioner.

Tabel 10

Hasil Uji Normalitas Kolmogorov-Smirnov

\begin{tabular}{|c|c|c|}
\hline & $\begin{array}{l}\text { Unstandardized } \\
\text { Residual }\end{array}$ \\
\hline $\begin{array}{l}\text { N } \\
\text { Normal } \\
\text { Parameters }{ }^{\mathrm{a}, \mathrm{b}} \\
\text { Most Extreme } \\
\text { Differences } \\
\text { Kolmogorov-S } \\
\text { Asymp. Sig. (2 }\end{array}$ & $\begin{array}{l}\text { Mean } \\
\text { Std. Deviation } \\
\text { Absolute } \\
\text { Positive } \\
\text { Negative } \\
\text { irnov Z } \\
\text { ailed) }\end{array}$ & $\begin{array}{r}35 \\
, 0000000 \\
1,55203634 \\
, 098 \\
, 082 \\
-, 098 \\
, 579 \\
, 891\end{array}$ \\
\hline
\end{tabular}

Berdasarkan tabel 10 di atas, adapun hasil pengujian normalitas pada kolom kolmogrovSmirnov dapat diketahui bahwa nilai Asymp.Sig.(2-tailed) 0,891>0,05. Maka dapat disimpulkan bahwa data residual terdistribusi

Tabel 11

Hasil Analisis Regresi Linear Berganda Coefficients $^{\mathrm{a}}$

\begin{tabular}{|c|c|c|c|c|c|}
\hline Variabel & $\begin{array}{l}\text { Coeffi } \\
\text { cients } \\
\text { Regres } \\
\text { i }\end{array}$ & $\begin{array}{c}\text { Coeffici } \\
\text { ents } \\
\text { Beta }\end{array}$ & $t_{\text {hitung }}$ & $\mathrm{t}_{\text {tabel }}$ & Sig. \\
\hline $\begin{array}{l}\text { (Constan } \\
\text { t) }\end{array}$ & .865 & & .332 & 2.002 & .002 \\
\hline $\begin{array}{l}\text { TOTAL } \\
\mathrm{X} 1\end{array}$ & .201 & . 155 & 2.642 & 2.002 & .001 \\
\hline $\begin{array}{l}\text { TOTAL } \\
\text { X2 }\end{array}$ & .238 & .299 & 2.126 & 2.002 & .000 \\
\hline $\begin{array}{l}\text { DF }=60 \\
-2=58\end{array}$ & \multicolumn{2}{|c|}{$\begin{array}{l}\mathrm{R}=0,325 \\
\mathrm{R}^{2}=0,116 \\
\text { Adjusted } \mathrm{R}^{2}= \\
0,545\end{array}$} & \multicolumn{3}{|c|}{$\begin{array}{l}F_{\text {hitung }}=4,098 \\
F_{\text {tabel }}=3.16\end{array}$} \\
\hline
\end{tabular}

normal.

Berdasarkan tabel 11 di atas dapat dilihat koefisien dari masing masing variabel dan konstanta yang menjadi observasi dalam penelitian ini adalah koefisien $\left(X_{1}\right)$ 0,201, koefisien $\left(X_{2}\right)$ 0,238 dan Konstanta 0,865 hal ini berarti variabel indeependen berpengaruh terhadap strategi pengamanan penerimaan pajak. Secara persamaan dapat ditulis sebagai berikut:

$Y=0,865+0,201 X_{1}+0,236 X_{2}+e$
Persamaan regresi di atas mempunyai makna sebagai berikut:

a. Konstanta $\alpha$ sebesar 0,865 , hal ini menunjukkan bahwa jika tidak ada peningkatan /penurunan nilai variabel X1 dan X2, maka pelaporan akuntansi sumber daya manusia adalah sebesar 0,865

b. Jika biaya sumber daya manusia meningkat satu satuan maka pelaporan akuntansi sumber daya manusia akan meningkat sebesar 0,201

c. Jika pengukuran nilai sumber daya manusia meningkat satu satuan maka pengukuran nilai sumber daya manusia akan meningkat sebesar 0,236

Tabel 12

Hasil Uji Parsial (Uji t) Coefficients $^{\text {a }}$

\begin{tabular}{|l|r|r|r|r|r|}
\hline & \multicolumn{2}{|c|}{$\begin{array}{c}\text { Unstandardi } \\
\text { zed } \\
\text { Coefficients }\end{array}$} & $\begin{array}{c}\text { Standar } \\
\text { dized } \\
\text { Coeffici } \\
\text { ents }\end{array}$ & & \\
\cline { 2 - 4 } Model & B & \multicolumn{1}{c|}{$\begin{array}{c}\text { Std. } \\
\text { Error }\end{array}$} & Beta & \multicolumn{1}{c|}{$\mathrm{T}$} & \multicolumn{1}{|c|}{ Sig. } \\
\hline $\begin{array}{l}\text { 1(Constan } \\
\text { t) }\end{array}$ & .865 & .232 & & .322 & .002 \\
$\begin{array}{l}\text { TOTAL } \\
\text { X1 }\end{array}$ & .201 & .201 & .155 & 2.642 & .001 \\
$\begin{array}{l}\text { TOTAL } \\
\text { X2 }\end{array}$ & .238 & .238 & .299 & 2.126 & .000 \\
\hline
\end{tabular}

Berdasarkan Tabel 12 diatas dapat dilihat bahwa nilai thitung untuk variabel biaya sumber daya manusia $\left(\mathrm{X}_{1}\right)$ sebesar 2,642 dan pengukuran nilai sumber daya manusia $\left(\mathrm{X}_{2}\right)$ sebesar 2,126. Untuk mengetahui tingkat pengaruh variabel bebas terhadap variabel terikat secara parsial, maka dapat dilihat pada pengujian hipotesis dengan uji $\mathrm{t}$ dilakukan dengan membandingkan antara $t_{\text {hitung }}$ dengan $t_{\text {tabel }}$ sebagai berikut:

a. Pembuktian hasil pengujian hipotesis variabel biaya sumber daya manusia $\left(\mathrm{X}_{1}\right)$ secara parsial (uji t) yang diperoleh dari nilai thitung pada persamaan regresi linear berganda menyatakan bahwa biaya sumber daya manusia berpengaruh terhadap pelaporan akuntansi sumber daya dikarenakan $t_{\text {hitung }}$ sebesar 2,642 dan $t_{\text {tabel }}$ sebesar 2,002 dimana $t_{\text {hitung }}>t_{\text {tabel }}$. Sehingga hipotesis pertama $\left(\mathrm{H}_{1}\right)$ diterima.

b. Pembuktian hasil pengujian hipotesis variabel pengukuran nilai sumber daya 
manusia $\left(\mathrm{X}_{2}\right)$ secara parsial (uji t) yang diperoleh dari nilai $t_{\text {hitung }}$ pada persamaan regresi linear berganda menyakatan bahwa pengukuran nilai sumber daya manusia berpengaruh terhadap pelaporan akuntansi sumber daya manusia, dikarenakan $t_{\text {hitung }}$ sebesar 2,126 dan $t_{\text {tabel }}$ sebesar 2,002 dimana $t_{\text {hitung }}>t_{\text {tabel}}$. Sehingga hipotesis kedua $\left(\mathrm{H}_{2}\right)$ diterima.

Tabel 13

Hasil Uji Simultan (Uji F)

\begin{tabular}{|c|c|c|c|c|c|}
\hline \multicolumn{6}{|c|}{ ANOVA $^{b}$} \\
\hline Model & $\begin{array}{c}\text { Sum of } \\
\text { Squares }\end{array}$ & Df & $\begin{array}{c}\text { Mean } \\
\text { Square }\end{array}$ & F & Sig. \\
\hline $\begin{array}{l}1 \text { Regressi } \\
\text { on }\end{array}$ & 4.145 & 2 & 27.072 & 4.121 & .0 \\
\hline Residual & 76.589 & 57 & 6.607 & & \\
\hline Total & 30.733 & 59 & & & \\
\hline
\end{tabular}

Dari hasil perhitungan pada tabel di atas dapat diketahui bahwa nilai $F_{\text {hitung }}$ sebesar 4,098 > $F_{\text {tabel }}$ sebesar 3,16 maka hipotesis diterima dan dapat disimpulkan bahwa variabel bebas, biaya sumber daya manusia $\left(\mathrm{X}_{1}\right)$ dan pengukuran nilai sumber daya manusia $\left(\mathrm{X}_{2}\right)$ secara bersama-sama berpengaruh terhadap pelaporan akuntansi sumber daya manusia $(\mathrm{Y})$ sehingga hipotesis $\left(\mathrm{H}_{3}\right)$ diterima.

\section{PEMBAHASAN}

Hasil uji secara parsial (uji-t) biaya sumber daya manusia, yaitu nilai $t_{\text {hitung }}$ sebesar $2,642>t_{\text {tabel }}$ 2,002. Dengan demikian, dapat dikatakan bahwa biaya sumber daya manusia berpengaruh secara parsial terhadap pelaporan akuntansi sumber daya manusia. Hal ini membuktikan bahwa biaya sumber daya manusia memiliki korelasi terhadap pelaporan akuntansi sumber daya manusia. Hal ini dikarenakan bahwa sebuah laporan keuangan khususnya laporan sumber daya manusia tidak akan lepas dari biayabiaya yang dikeluarkan untuk sumber daya manusia itu sendiri, dimana biaya-biaya yang dikeluarkan oleh PT Bank Aceh Syariah untuk keperluan sumber daya manusia seperti gaji, tunjangantunjangan serta biaya lain yang harus dikeluarkan oleh perusahaan sudah cukup baik dicatat di dalam laporan akuntansi sumber daya manusia. Sehingga dapat membantu pihak manajemen untuk mengembangkan, mengalokasikan, menghemat dan mengevaluasi sumber daya manusia dengan baik dan sesuai dengan tujuan yang hendak dicapai oleh perusahaan, serta memudahkan dalam pengambilan keputusan yang berkaitan dengan sumber daya manusia.

Hasil uji secara parsial (uji t) pengukuran nilai sumber daya manusia, yaitu nilai $t_{\text {hiutng }}$ sebesar $2,126>t_{\text {tabel }}$ 2,002. Dengan demikian, dapat dikatakan bahwa pengukuran nilai sumber daya manusia berpengaruh terhadap pelaporan akuntansi sumber daya manusia. Hal ini membuktikan bahwa pengukuran nilai sumber daya manusia memiliki korelasi terhadap pelaporan akuntansi sumber daya manusia dikarenakan pelaporan tentang kontribusi serta investasi yang diberikan oleh karyawan harus berdasarkan pengukuran yang telah ditetapkan seperti terukurnya prestasi serta nilai lebih karyawan yang dicatat dalam laporan akuntansi sumber daya manusia. Di PT Bank Aceh Syariah sendiri pengukuran yang dilakukan terhadap sumber daya manusia sudah sesuai dengan prosedur yang telah ditetapkan. Dengan adanya pengukuran yang baik atas nilai lebih karyawan maka laporan yang dihasilkan akan lebih akurat serta handal. Dan hal ini akan berguna bagi pengambil keputusan di PT Bank Aceh Syariah dalam hal menindaklanjuti sumber daya manusianya.

Hasil penelitian menunjukkan $F_{\text {hitung }}$ sebesar 4,145 sedangkan $F_{\text {tabel }}$ sebesar 3,16 terlihat $F_{\text {hitung }}>F_{\text {tabel }}$, sehingga dapat membuktikan bahwa pengaruh biaya sumber daya manusia dan pengukuran nilai sumber daya manusia secara simultan berpengaruh terhadap pelaporan akuntansi sumber daya manusia. Berdasarkan hasil pengujian tersebut dapat diketahui bahwa kedua variabel yaitu biaya sumber daya manusia $\left(\mathrm{X}_{1}\right)$ dan pengukuran nilai sumber daya manusia $\left(X_{2}\right)$ mampu memberikan pengaruh terhadap pelaporan akuntansi sumber daya manusia. Biaya sumber daya manusia dan pengukuran nilai sumber daya manusia merupakan hal yang tidak bisa dipisahkan dari laporan akuntansi sumber daya manusia karena tidak akan terciptanya suatu laporan sumber daya manusia apabila tidak adanya biaya yang dikeluarkan dan pengukuran nilai lebih atau kontriusi yang diberikan oleh sumber daya manusia itu sendiri. Dengan demikian biaya sumber daya manusia $\left(\mathrm{X}_{1}\right)$ dan pengukuran nilai sumber daya manusia $\left(\mathrm{X}_{2}\right)$ mempunyai pengaruh terhadap pelaporan akuntansi sumber daya manusia $(\mathrm{Y})$.

\section{PENUTUP}

Kesimpulan 
Berdasarkan hasil penelitian dan pembahasan yang telah diuraikan, maka penulis mengemukakan kesimpulan sebagai berikut:

1. Biaya sumber daya manusia berpengaruh terhadap pelaporan akuntansi sumber daya manusia. Hal ini dikarenakan unsur biaya sumber daya manusia adalah hal yang tidak dapat dipisahkan dari sebuah pelaporan akuntansi sumber daya manusia.

2. Pengukuran nilai sumber daya manusia berpengaruh terhadap pelaporan akuntansi sumber daya manusia. Hal ini dikarenakan pengukuran nilai sumber daya manusia akan menghasilakan berapa nilai yang dimiliki oleh seorang sumber daya manusia tersebut dan nilai tersebut akan dimasukkan ke dalam laporan akuntansi sumber daya manusia.

3. Biaya sumber daya manusia dan pengukuran nilai sumber daya manusia berpengaruh secara simultan terhadap pelaporan akuntansi sumber daya manusia. Hal ini dikarenakan kedua variabel tersebut merupakan unsur yang melekat dan tidak dapat dipisahkan dari laporan akuntansi sumber daya manusia. Apabila tidak adanya kedua unsur tersebut maka tidak akan terciptanya sebuah laporan akuntansi sumber daya manusia.

Saran

Adapun saran yang dapat diberikan peneliti dalam penelitian ini adalah sebagai berikut:

1. Bagi peneliti selanjutnya diharapkan dapat memperluas populasi dan objek penelitian seperti menambahkan beberapa objek lagi agar populasi maupun sampel dalam penelitian tidak terbatas

2. Jika populasinya banyak, maka dapat menggunakan metode pengambilan sampel secara acak ataupun secara berkriteria untuk memperoleh sampel yang mampu mencerminkan keseluruhan populasi dan lebih objektif

3. Kemudian dapat menambahkan variabel independen yang lain dan dapat sumber data menggunakan data sekunder.

\section{Keterbatasan Penelitian}

Penelitian ini memiliki keterbatasan yang dapat mempengaruhi hasil penelitian. Keterbatasan penelitian tersebut antara lain:

1. Penelitian ini hanya menggunakan tiga variabel, yaitu biaya sumber daya manusia dan pengukuran nilai sumber daya manusia dan pelaporan akuntansi sumber daya manusia.

2. Responden yang digunakan sebagai sampel hanya terbatas dalam satu populasi.
3. Penelitian ini menggunakan data primer, jika menggunakan data sekunder maka akan lebih terlihat pengaruh secara moneternya.

\section{DAFTAR PUSTAKA}

Alafi, S Faiz dan Sri Suranta. (2018). Pengungkapan Akuntansi Sumber Daya Manusia dan Kinerja Keuangan Perusahaan. Universitas Sebelas Maret.

Annual Report PT. Bank Aceh Syariah. (2015). Laporan Sumber Daya Insani Human Resources Reports.

(2016). Laporan Sumber Daya Insani Human Resources Reports.

(2017). Laporan Sumber Daya Insani Human Resources Reports.

Astari, Ni Ketut Aci Ega dan Ananta Tungga Atmadja. (2017). Analisis Penerapan Akuntansi Sumber Daya Manusia Pada RS Kertha Usada Buleleng. Jurusan Akuntansi. Unversitas Pendidikan Ganesha.

Ghozali, Imam. (2011). Aplikasi Analisis Multivariate dengan Program IBM SPSS 19. Edisi Kelima. Semarang. Universitas Diponegoro.

Gustiyar, Cecep. (2010). Pengaruh Biaya Sumber Daya Manusia Dan Pengukuran Nilai Sumber Daya Manusia Terhadap Laporan Akuntansi Sumber Daya Manusia Pada PT. Bank Riau Pekanbaru. Program Studi Akuntansi. Fakultas Ekonomi dan Ilmu Sosial. Universitas Islam Negeri Sultan Syarif Kasim Riau Pekanbaru.

Harahap, Sofyan Syafri. (2011). Teori Akuntansi. Edisi Revisi 2011. Jakarta: Rajawali.

Harimurti, Yohanes. (2011). Pengukuran Nilai Sumber Daya Manusia Pada Lembaga Pendidikan dengan Compenstion Model. Fakulas Ekonomi. Universitas Katolik Widya Mandala Surabaya.

Haryanto, Agus. (2013). Penerapan Akuntansi Sumber Daya Manusia Dalam Laporan Keuangan. Sekolah Tingkat Ilmu Ekonomi Dharmaputra. 
Ikhsan, Arfan. (2010). Akuntasi Sumber Daya Manusia. Cetakan Pertama. Yogyakarta. Graha Ilmu.

Indriantoro, Nur dan Supomo. (2014). Metodologi Penelitian Bisnis untuk Akuntansi \& Manajemen. Yogyakarta: BPFE.

Jogiyanto, H. (2013). Metodologi Penelitian Bisnis Salah Kaprah dan Pengalamanpengalaman. Edisi Keenam. Yogyakarta: BPFE-Yogyakarta

Mulyadi. (2015). Akuntansi Biaya. Edisi 5. Yogyakarta: Sekolah Tinggi Ilmu Manajemen YKPN.

Purwaji, Agus, dkk. (2018). Akuntansi Biaya, Edisi 2. Jakarta: Salemba Empat

Rahayu, Tiara Dwiandiani, Nurcholisah, dkk (2016). Pengaruh Biaya Sumber Daya Manusia Dan Pengukuran Nilai Sumber Daya Manusia Terhadap Pelaporan Akuntansi Sumber Daya Manusia Pada PT. Dirgantara Indonesia. Program Studi Akuntansi. Fakultas Ilmu Ekonomi dan Bisnis. Universitas Islam Bandung.

Sari, Rani Novita. (2016). Pengaruh Biaya Pengembangan Sumber Daya Manusia Terhadap Pelaporan Akuntansi Sumber Daya Manusia Pada Perusahaan Daerah Air Minum Kota Samarinda. Program Studi Akuntansi. Fakultas Ekonomi dan Bisnis. Universitas Mulawarman, Indonesia.

Standar Akuntansi Keuangan (SAK). (2002). Dalam Kerangka Dasar Penyusunan dan Penyajian Laporan Keuangan. Tahun 2002, hal. 13, paragraf 49.

Sugiyono. (2010). Metodelogi Penelitian Kuantitatif, Kualitatif dan R\&D. Bandung: Alfabeta.

(2011). Metodelogi Penelitian Kuantitatif, Kualitatif dan R\&D. Bandung: Alfabeta.

(2012). Metodelogi Penelitian Kuantitatif, Kualitatif dan R\&D. Bandung: Alfabeta.

.(2013). Metodelogi Penelitian Kuantitatif, Kualitatif dan R\&D. Bandung: Alfabeta.
Tunggal, Amin Widjaya. (2009). Akuntansi Manajemen. Buku 2. Harva Rindo: Jakarta.

Warno. (2011). Pengaruh Pengukuran Nilai Sumber Daya Manusia Terhadap Pelaporan Akuntansi Sumber Daya Manusia Pada Perusahaan Daerah Air Minum Sumedang. Sekolah Tinggi Ilmu Ekonomi Semarang.

Wirawan. (2015). Manajemen Sumber Daya Manusia. Jakarta: PT Raja Grafindo Persada. 